\title{
The effects of large beach debris on nesting sea turtles
}

2

Ikuko Fujisaki $^{\mathrm{a}^{*}}$ and Margaret Lamont ${ }^{\mathrm{b}}$

${ }^{a}$ University of Florida, Fort Lauderdale Research and Education Center, Davie, FL, USA 33314

${ }^{b}$ U.S. Geological Survey, Wetland and Aquatic Research Center, Gainesville, FL, USA 32653

7

8 *Corresponding Author:

9 Ikuko Fujisaki

10 University of Florida

11 Fort Lauderdale Research and Education Center

123205 College Ave

13 Davie, FL 33314

14 Office: (954)577-6382

15 Fax: (954)475-4125

16 Email: ikuko@ufl.edu 


\section{ABSTRACT}

19 A field experiment was conducted to understand the effects of large beach debris on sea turtle

20 nesting behavior as well as the effectiveness of large debris removal for habitat restoration.

21 Large natural and anthropogenic debris were removed from one of three sections of a sea turtle

22 nesting beach and distributions of nests and false crawls (non-nesting crawls) in pre- (2011-

23 2012) and post- (2013-2014) removal years in the three sections were compared. The number of

24 nests increased $200 \%$ and the number of false crawls increased $55 \%$ in the experimental section,

25 whereas a corresponding increase in number of nests and false crawls was not observed in the

26 other two sections where debris removal was not conducted. The proportion of nest and false

27 crawl abundance in all three beach sections was significantly different between pre- and post-

28 removal years. The nesting success, the percent of successful nests in total nesting attempts

29 (number of nests + false crawls), also increased from $24 \%$ to $38 \%$; however the magnitude of the

30 increase was comparably small because both the number of nests and false crawls increased, and

31 thus the proportion of the numbers of nests and false crawls in the experimental beach in pre-

32 and post-removal years was not significantly different. The substantial increase in sea turtle

33 nesting activities after the removal of large debris indicates large debris may have an adverse

34 impact on sea turtle nesting behavior. Removal of large debris could be an effective restoration

35 strategy to improve sea turtle nesting.

36

37 Keywords: beach debris, false crawl, habitat restoration, nesting, sea turtle 
Coastal areas provide critical habitats for a variety of wildlife, and conservation of this

42 habitat is essential to maintaining high coastal biodiversity. Accelerated loss and degradation of

43 coastal habitats by anthropogenic and natural forces have been major threats for the populations

44 that rely on these habitats (Defeo et al., 2009). Marine debris has been identified as one source of

45 habitat degradation and threat to coastal and marine species (Laist, 1997). Marine debris can

46 result from various human activities, such as intense development and increased recreational use

47 of coastal habitats, commercial fisheries, and use of other ocean based resources by rapidly

48 expanding human populations, and natural events such as currents and tropical weather systems

49 (Ribic et al., 2010). Debris that enters the ocean environment can be transported by ocean

50 currents for long distances and then deposited on coastlines or ocean floors (Sheavly and

51 Register, 2007).

Many studies provide evidence of the negative impacts of marine debris on coastal and

53 marine species (see Gall and Thompson, 2015 for review). Sea turtles are among those 690

54 species whose populations have been affected by marine debris; six of all seven turtle species are

55 affected (Laist, 1997). Death, injuries, and stranding of sea turtles as a result of accidental

56 ingestion of and entanglement by marine debris are well documented (Laist, 1997; Schuyler et al.,

57 2013). However, debris not only impacts turtles in the water but also on the beaches. Sea turtles

58 spend most of their lives at sea, but they rely on sandy beaches for reproduction. During the

59 nesting season, females emerge from the water to deposit clutches of eggs in the sand.

60 Occasionally, turtles emerge from the water but do not deposit a clutch, and this is termed a false

61 crawl (Miller, 1997). Presence of large debris on a beach could interrupt nesting activities by

62 turtles causing false crawls. Frequent abortion or disruption on nesting attempts by leatherback

63 turtles was observed in a beach in Gabon in Central Africa where active industrial logging 
64 caused accumulation of logs on the beach (Laurence et al., 2008). Additionally, nest placement

65 may be affected by debris which could affect hatching success (Hays and Speakman, 1993).

66 Large debris may act as sea walls and prevent adult and hatchling turtles from traversing the

67 beach. Witherington et al. (2011) showed turtles nested closer to the water in areas where sea

68 walls were present as compared to areas without walls. Another study in Gabon indicated that

$69 \operatorname{logs}$ on the beach, combined with artificial lights, caused disorientation for leatherback

70 hatchlings (Burgeios et al., 2009).

71 The objective of this study was to examine how large debris influences the nesting

72 behavior of sea turtles and to assess the effectiveness of large debris removal as a restoration

73 activity to improve sea turtle nesting habitat. A field experiment was conducted to compare the

74 relative abundance of nests and false crawls before and after large debris removal from a portion

75 of a loggerhead turtle nesting beach.

76

77 2. Material and methods

792.1 Study area

80 This study was conducted along approximately $5.7 \mathrm{~km}$ of beach on Eglin Air Force Base

81 property on Cape San Blas in northwest Florida (Fig. 1). This area represents the southern tip of

82 the St. Joseph Peninsula in Gulf County, Florida, and supports one of the greatest nesting

83 densities of loggerhead sea turtles in the northern Gulf of Mexico, where a severe decline in

84 loggerhead nests highlights the need for nesting habitat conservation (Lamont and Carthy, 2007;

85 Lamont et al., 2012). 
The study area has distinct sections due to the bathymetry and current dynamics of the

87 region. The eastern portion of the study site is an accreting beach that is relatively wide, whereas

88 beaches in the remaining parts of the study area are narrower and eroding (Lamont and Carthy,

89 2007, Lamont and Houser, 2014). Man-made and natural debris have accumulated in the study

90 area over time. Man-made debris includes construction materials such as concrete, pipes, and

91 metal fencing that remained on the beach after demolition of old military structures. Most of the

92 natural debris is coarse wooden debris (CWD), including fallen trees and stumps, which is a

93 result of the beach eroding into the adjacent stand of pine flatwoods.

94 The study beach was divided into three sections: north, middle, and east (Fig. 1). The

95 north $(1.3 \mathrm{~km})$ and middle $(1.7 \mathrm{~km})$ beaches represent narrow, eroded, and high debris-density

96 beaches. All debris in the north beach was natural debris from the adjacent stand, whereas the

97 middle beach had a mixture of natural and man-made debris. The east beach $(2.7 \mathrm{~km})$

98 represented a comparably well-preserved beach with a smaller amount of debris and a larger

99 beach width.

100

$101 \quad 2.2$ Nesting and debris surveys and debris removal

102 Sea turtle nest surveys were conducted every morning during the nesting season from

103 May 1 through November 1, 2011-2014 (two nesting seasons in each pre- and post-debris

104 removal conditions) on foot, by ATV, or by using a 4-wheel drive vehicle. All turtle crawls were

105 identified to species and the location of each nest and false crawl was recorded using a hand-held

106 GPS.

107

The type, GPS locations, and size (area) of all large emergent debris on the beach that

108 required mechanical removal were recorded from June - August, 2012. The Marine Debris Act 
109 (33 USC 1951 et seq. as amended by Title VI of Public Law 112-213) defines marine debris as

110 “Any persistent solid material that is manufactured or processed and directly or indirectly,

111 intentionally or unintentionally, disposed of or abandoned into the marine environment or Great

112 Lakes." However, because the focus of our study was physical site occupancy by debris, both

113 man-made and natural debris on the beach were measured. Sandy beach areas representing

114 potential turtle nesting sites were delineated by taking GPS measurements along the

115 dune/vegetation line and shoreline at low tide. All emergent debris in the middle beach, except

116 for a large concrete pad that broke the excavator, was removed by heavy machinery in December

1172012 , outside of the nesting/hatching seasons for sea turtles and shorebirds, to minimize the

118 disturbance to those species.

$120 \quad 2.3$ Analysis

121 A $45 \times 45 \mathrm{~m}$ grid shapefile which covers the sandy beach area between the shoreline and

122 dune line in all three sections (north, middle and east) of the study area was created using

123 ArcGIS 10.3 (Fig. 2). Grid cells were removed if more than half of their area was outside of the

124 sandy beach. The number of debris, areas of debris coverage, and numbers of loggerhead nests

125 and false crawls in each grid cell were calculated. The correlation $(r)$ between the nesting

126 parameters (number of nests and false crawls) and the debris amount and coverage areas was

127 assessed.

128 The number of nests in each beach section during the nesting season for pre- (2011-

129 2012) and post- (2013-2014) debris removal conditions was determined. The reason that two

130 years of survey data in each condition (pre- and post-debris removal) were used for analysis was

131 to capture some inter-annual variability in nesting number of sea turtles (Broderick et al. 2001). 
132 Using chi-square tests for difference in proportion, it was examined whether distribution of turtle

133 nests and false crawls in the three beach sections changed after removing large debris from the

134 middle beach. Nesting success was defined as the proportion of nesting crawls to total number of

135 crawls (number of nesting crawls + number of false crawls). Using the pre- and post-removal

136 data in the middle beach, where large debris was removed, a chi-square test was conducted to

137 examine whether the proportion of successful nesting attempts changed.

139 3. Results

140

In total 643 pieces of debris ( 77 pieces in the north, 483 pieces in the middle, and 20

142 pieces in the east beaches), were located and measure. These debris covered 2,047.9 $\mathrm{m}^{2}$, or

$1430.77 \%$ of the study area (Fig. 2A). The majority (624 of 643) were natural debris, covering 94\%

144 of the debris-covered area. The most frequently observed debris was CWD; therefore each piece

145 of debris was typically long and narrow, with a mean length and width of $5.8 \mathrm{~m}$ and $0.5 \mathrm{~m}$

146 respectively. The density (number $/ \mathrm{km}$ ) of the debris was 58.5, 277.6, and 7.4 respectively on the

147 north, middle, and east beaches, covering $1.00 \%, 2.42 \%$, and $0.03 \%$ of each beach area.

148 In total, 160 loggerhead nests were recorded in the three beach sections (areas where

149 debris remained plus areas where debris was removed) from 2011 to 2014. Of the 160,76 of

150 these nests were deposited in pre-removal years (2011-2012) and 84 nests were deposited in

151 post-removal years (2013-2014; Figs. 3 and 4). The observed number of false crawls was 301

152 during the four-year period: 170 during the pre-removal years and 131 during the post-removal

153 years (Figs. 3 and 4). 
The number of nests observed in each $45 \mathrm{~m}$ grid cell was not significantly correlated with

155 both number of debris $(r=-0.05)$ and area covered by debris $(r=-0.06)$ in the grid cell during

156 the pre-removal nesting seasons (2011-2012; Fig. 2B). Similarly, the number of false crawls

157 observed in each grid cell was not significantly correlated with both the amount of debris $(r=$

$1580.10)$ and the area covered by debris $(r=0.08)$.

159 The number of nests observed from pre-removal years (2011-2012) to post-removal

160 years (2013-2014) tripled from 9 to 27 nests in the middle beach where large debris were

161 removed. However, such an increase was not observed in the two other sections. The number of

162 nests declined by $46 \%$ in the north beach (24 nests in 2011-2012 and 13 nests in 2013-2014)

163 and the number was nearly equivalent (43 nests in 2011-2012 and 44 nests in 2013-2014) in the

164 east beach (Fig. 4). In comparing pre- and post-removal states, the distribution of nests in the

165 three beach sections was significantly different $\left(\chi^{2}=12.5, p<0.01\right)$. During pre-removal years,

166 number of nests placed in the middle beach was $12 \%$ of the nests placed in the entire study area,

167 but it increased to $32 \%$ after the removal. The number of false crawls from pre-removal and

168 post-removal years increased $55 \%$ in the middle beach, from 29 to 45 , but it decreased $52 \%$

169 (from 42 to 20) in the north beach and 33\% (from 99 to 66) in the east beach (Fig. 4). The

170 change in the distribution of the false crawls from pre- and post-removal was also significant $\left(\chi^{2}\right.$

$171=13.03, p<0.01)$. The substantial increase in number of nests resulted in overall increase in nest

172 success rate from $24 \%$ to $38 \%$ in the middle beach, but this change was not significant $\left(\chi^{2}=2.16\right.$,

$173 p=0.14)$.

174

175 4. Discussion 
The results showed that the presence of large debris on a sandy beach could alter the

177 spatial distribution of sea turtle nests by influencing turtle nest site selection. Whereas negative

178 impacts of marine debris on sea turtles has been recognized, few studies have focused on the

179 impacts of beach debris on sea turtle reproduction (Laurence et al., 2008; Bourgeois et al., 2009;

180 Witherington et al., 2011), and the authors did not recognize any study that experimentally tested

181 the effect of large debris on sea turtle nesting activities as was done in this study. Although the

182 grid pattern analysis did not support a strong correlation between sea turtle nesting activities and

183 the presence and coverage of beach debris, the results from the field experiment showed removal

184 of large debris may contribute to increases in nesting activity (both number of nests and false

185 crawls). In fact, the number of nests largely declined (46\%) on a control beach (north beach)

186 which is consistent with the recent, steep declining loggerhead nesting trend in this area (Lamont

187 et al., 2012). It should be noted that there are other factors which may contribute to variations in

188 abundance and distribution of nesting activity on this beach. At the study site, in line with

189 conclusions from elsewhere in the sea turtle nesting areas, a broad range of factors may cause

190 different nesting densities on adjacent beaches, including current direction, wave height, lighting

191 and offshore bathymetry (Godley et al. 2001, Lamont and Houser 2014). The changes in nest

192 distribution observed in this study may have also been affected by these factors; however the fact

193 that substantial increased in nesting activity occurred only in the section where debris was

194 suggests debris removal was a significant factor contributing to these changes. Although the

195 increase of false craws after the debris removal was not expected, it happened likely because

196 removal of large debris close to the water line allowed turtles to crawl on the beach whereas the

197 area was previously blocked. The nest success at the post-debris removal (38\%) was higher than

198 that of pre-removal stage (24\%); however, because both number of nests and false crawls 
199 increased, the observed magnitude of the increase (14\%) in the success rate was not substantially $200 \quad$ large and statistically insignificant.

201 Both large man-made and natural debris were present in the study area. As it was 202 observed at a number of other sea turtle nesting beaches (Laurence et al. 2008, Bourgeois et al. 203 2009, Triessnig et al. 2012), both large man-made and natural debris were covering sandy beach

204 areas in the study site. Natural debris on the beach could occur as a result of processes in the 205 ecosystem such as tropical storms and ocean currents, human activities such as industrial logging, 206 or a combination of both. In our study area, natural debris (mainly CWD) comprised most of the 207 debris-covered area. Although natural debris could eventually degrade, large and heavy man208 made debris (mainly construction materials such as concrete, tubes, and metals found in our 209 study area) are non-degradable, and thus could permanently occupy the site unless removed. 210 Further, debris could eventually be covered by sand and become visually undetectable, making it 211 difficult to remove. In this study, only emerged debris which appeared on the surface were 212 measured, but debris buried completely under the sand were found during the measurement and 213 removal process. Presence of submerged debris could also influence sea turtle nesting by 214 preventing turtles from digging nest chambers in which to deposit eggs, which may contribute to 215 an increase in false crawls.

216 Area-wise, debris covered a small proportion of the entire study beach (2\% of the beach 217 area in the most severely debris-covered section), but removal of debris resulted in a substantial 218 increase in nesting activities. This is likely because these large and typically long pieces of debris 219 block turtle crawls thereby preventing them from nesting. Although only nesting activities 220 (number of nests and false crawls) were examined in this study, large debris may also negatively 221 influence hatchling success and survival (Hays and Speakman, 1993; Burgeios et al., 2009), 
222 which is another important aspect of sea turtle reproduction. Further, implications from this

223 study may be extended to other species, such as shorebirds which nest and forage on sandy

224 beaches, because large debris could occupy their nesting and foraging areas. Last, it should be

225 noted that caution is required when removing large debris on the shoreline because accumulation

226 of CWD could serve as an erosion control in some instances (Eamer and Walker, 2010). In

227 addition, timing of removal is an important consideration in order to avoid sea turtle and

228 shorebird nesting and hatching seasons and minimize disturbance to existing wildlife populations.

\section{5. Conclusions}

231 Marine debris is an indicator of habitat quality for sea turtle nesting sites (Triessnig et al.

232 2012). The results of this suggest that removal of large debris may open nesting habitat that was

233 previously unavailable for sea turtle nesting. Given that degradation of sandy beaches is expected

234 to further intensify in the coming decades due to continuously increasing human populations

235 (James, 2000; Arizma et al., 2008), it could be an effective conservation method, especially in

236 critical habitats for imperiled species such as sea turtles.

\section{Acknowledgements}

Authors are grateful for Melanie Gang, Meg Goecker, Laurie Rounds, Kimberly Albins,

241 and Tom Barry with National Oceanic and Atmospheric Administration (NOAA) for their advice

242 in conducting the large debris removal. Carri Herring with NOAA provided an insightful review

243 to improve the manuscript. Eglin Air Force Base and contractors provided personnel and

244 logistical support for large debris removal, and the Eglin Natural Resources Branch provided 
long-term support for sea turtle nesting surveys. Authors thank Brail Stephens, Caitlin Hackett,

246 Amanda Vazquez, Phillip Rodgers, and Garret Alver for field data collection and Daniel

247 Cardona for assisting in the GIS work. This study was funded by NOAA's Marine Debris

248 program (NA12NMF6430070). Any use of trade, product, or firm names is for descriptive

249 purposes only and does not imply endorsement by the U.S. Government.

\section{References:}

Ariza, E., Jiménez, J.A., Sardá, R., 2008. A critical assessment of beach management on the Catalan coast. Ocean. Coast. Manage. 51,141-160.

Bourgeois, S., Gilot-Fromont, E., Viallefont, A., Boussamba, F., Deem, S.L., 2009. Influence of artificial lights, logs and erosion on leatherback sea turtle hatchling orientation at Pongara National Park, Gabon. Biol. Conser. 142, 85-93.

Defeo, O., McLachlan, A., Schoeman, D.S., Schlacher, T.A., Dugan, J., Jones, A., Lastra, M., Scapini, F., 2009. Threats to sandy beach ecosystems: A review. Estuar. Coast Shelf. Si. 2009, 1-12.

Eamer, H.B.R., Walker, I.J., 2010. Quantifying sand storage capacity of large woody debris on beaches using LiDAR. Geomorphology 118, 33-47.

Gall, S.C., Thompson, R.C., 2015. The impact of debris on marine life. Mar. Pollut. Bull. 91, $170-179$.

Godley, B.J., Broderick, A.C., Hays, G.C. 2001. Nesting of green turtles Chelonia mydas at Ascension Island, South Atlantic. Biol. Conser. 97, 151-158.

Hays, G.C., Speakman, J.R., 1993. Nest placement by loggerhead turtles, Caretta caretta. Animal Behav. 45, 47-53.

James, R.J., 2000. From beaches to beach environments: linking the ecology, human-use and management of beaches in Australia. Ocean Coast Manage. 43, 495-514.

Laist, D.W., 1997. Impacts of marine debris: entanglement of marine life in marine debris including a comprehensive list of species with entanglement and ingestion records. In: Coe JM, DB Rodgers (Eds.), Marine Debris - Sources, Impacts and Solutions. SpringerVerlag, New York, pp. 99-139.

Lamont, M.M., Carthy, R.R., 2007. Response of nesting sea turtles to barrier island dynamics. Chelonian Conserv.Biol. 6, 206-212.

Lamont, M.M, Carthy, R.R., Fujksaki, I. 2012. Declining reproductive parameters highlight conservation needs for loggerhead turtles (Caretta caretta) in the northern Gulf of Mexico. Chelonian Conserv. Biol. 11, 190-196.

Lamont, M.M., Houser, C., 2014. Spatial distribution of loggerhead turtle (Caretta caretta) emergences along a highly dynamic beach in the northern Gulf of Mexico. J. Exp. Marine Biol. 453, 98-107.

Laurence, W.F., Fay, J.M., Parnell, R.J., Sounguet, G-P., Formia, A., Lee, M.E., 2008. Does rainforest logging threaten marine turtles? Oryx 42, 1-6. 
Miller, J.D., 1997. Reproduction in sea turtles. In: The Biology of Sea Turtles (eds Lutz PK, Musick JA), pp. 51-81. CRC Press, Boca Raton, FL.Morton RA., Miller TL., Moore LJ. 2004 National assessment of shoreline change: Part 1: Historical shoreline changes and associated coastal land loss along the U.S. Gulf of Mexico: U.S. Geological Survey Open-file Report 2004-1043, 45p.

Ribic, C.A., Sheavly, S.B., Rugg, D.J., Erdmann, E.S., 2010. Trends and drivers of marine debris on the Atlantic coast of the United States 1997-2007. Mar. Pollut. Bull. 60, 1231-1242.

Schuyler, Q., Hardesty, B.D., Wilcox, C., Townsend, K., 2014. Global analysis of anthropogenic debris ingestion by sea turtles. Conserv. Biol. 28, 129-139.

Sheavly, S.B., Register, K.M., 2007. Marine debris \& plastics: environmental concerns, sources, impacts and solutions. J Polym. Environ. 15, 301-305.

Triessnig, P., Rpetzer, A., Stacjpwotzch, M., 2012. Beach condition and marine debris: new hurdles for sea turtle hatchling survival. Charonian Cons. Biol. 11, 68-77.

Witherington, B.E., Hirama, S., Mosier, A., 2011. Sea turtle responses to barriers on their nesting beach. J. Exp. Mar. Biol. Ecol. 410, 1-6. 


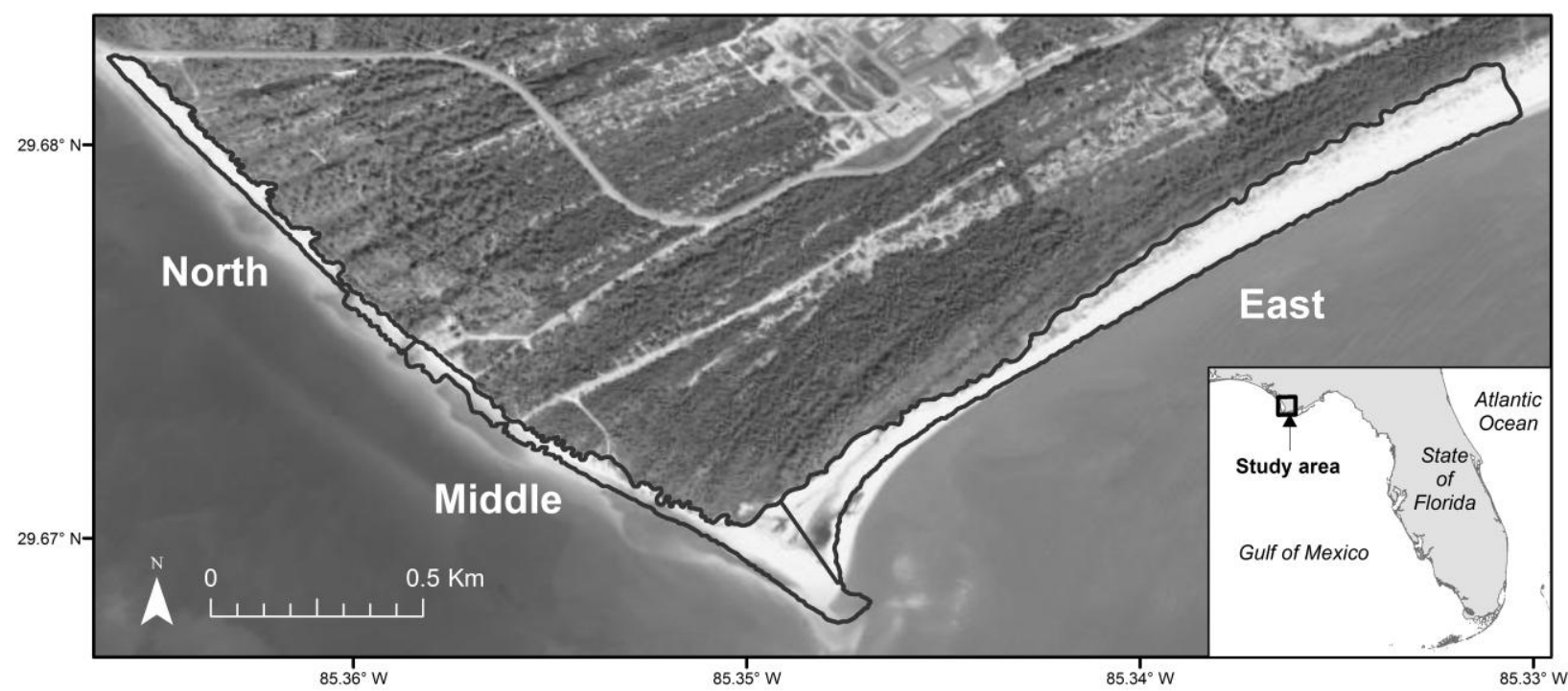

Figure 1. Map of Cape San Blas in St. Joseph Peninsula, Florida, in which the boundary of the three beach sections (north, middle, and east) of the study area is shown. The inset box shows the location of the study area within the state of Florida, USA. 

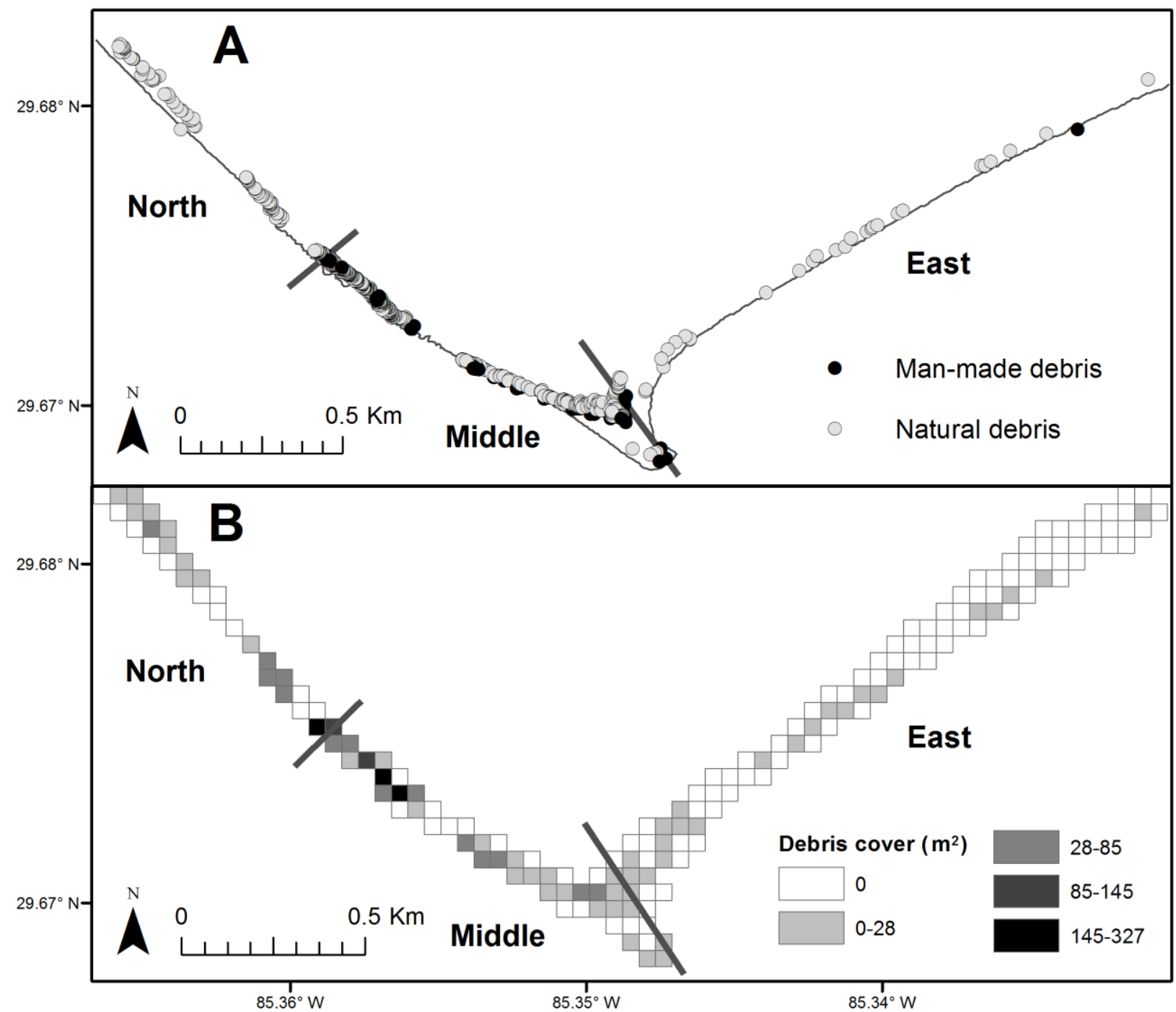

Figure 2. Location of observed large debris in Cape San Blas in St. Joseph Peninsula, Florida, from July-October, 2012 in which type of the debris (man-made or natural) were indicated by gray scale (A), and debris-covered area $\left(\mathrm{m}^{2}\right)$ within each $10 \mathrm{~m}^{2}$ grid cell (B) in three beach 


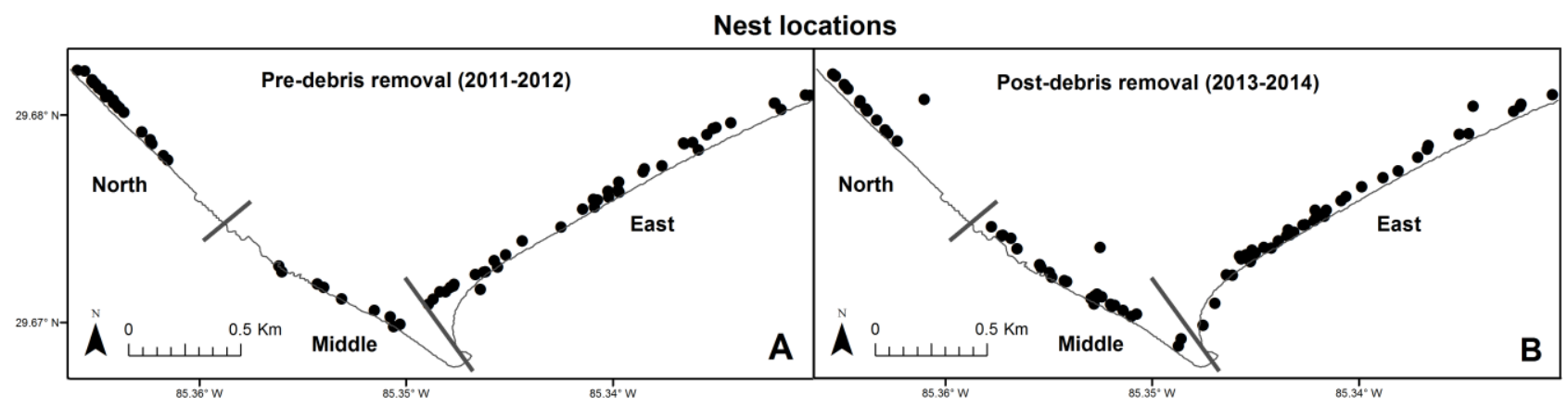

False crawl locations

312

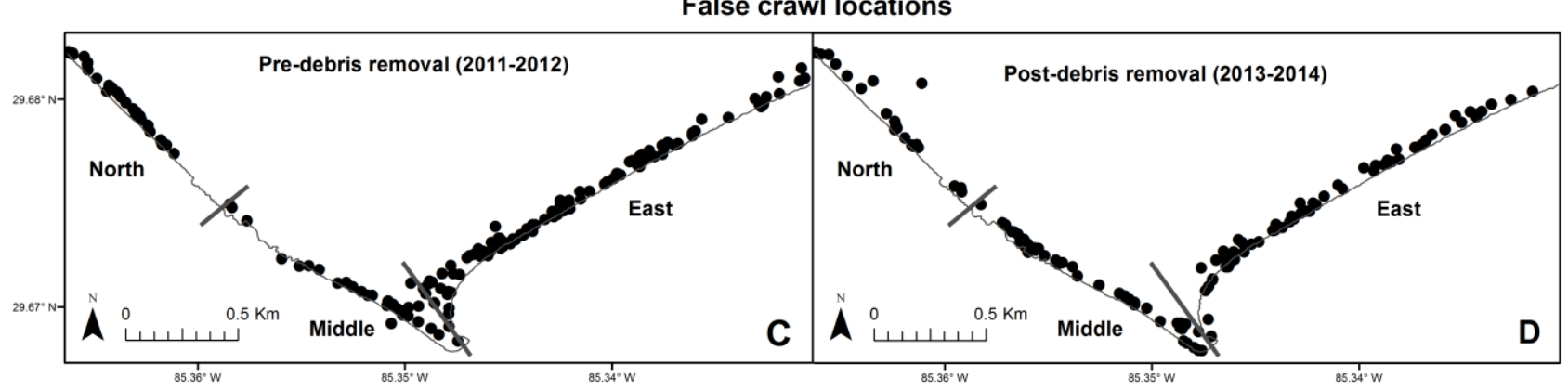

Figure 3. Mapped locations of loggerhead nests (A and B) and false crawls (C and D) during nesting seasons before (2011-2012) and after (2013-2014; bottom figures) the large debris removal in the middle beach in Cape San Blas in St. Joseph Peninsula, Florida. Points which appeared in substantially interior land due to GPS location errors are not shown in the map. 


\section{Nests}

Pre-debris removal (2011-2012)

A

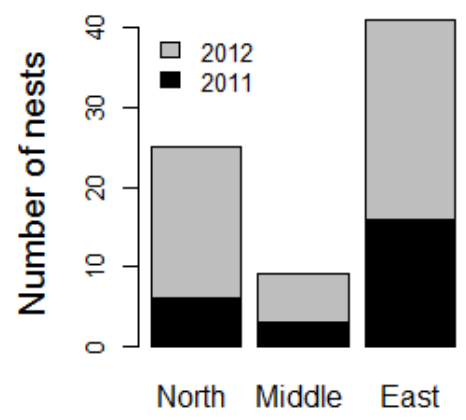

Post-debris removal (2013-2014)

B

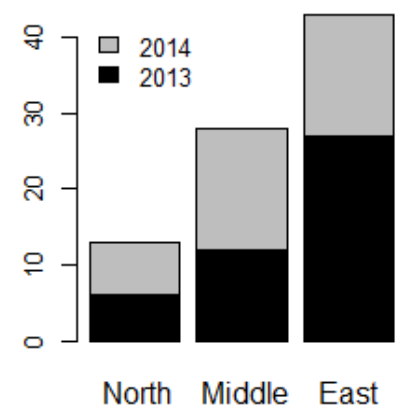

\section{False crawls}

Pre-debris removal (2011-2012)

C

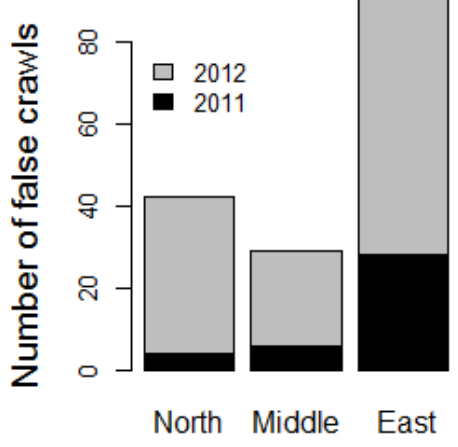

Post-debris removal (2013-2014)

Figure 4. Bar plots of number of loggerhead nests (A and B) and false craws (C and D) in three beach sections in Cape San Blas in St. Joseph Peninsula, Florida for two years before and after the large debris removal in the middle beach.

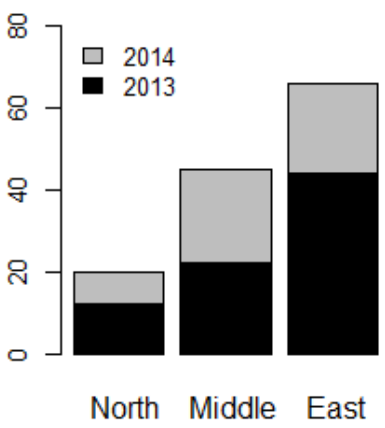

